\title{
APLIKASI PENGENALAN HURUF DAN ANGKA MENGGUNAKAN PENDEKATAN REALISTIK BERBASIS ANDROID
}

\author{
Wanti Rahayu ${ }^{1}$, Ari Irawan ${ }^{2 *}$ \\ Program Studi Teknik Informatika, Universitas Indraprasta PGRI ${ }^{1,2}$ \\ Email: ari irawan@unindra.ac.id
}

\begin{abstract}
Abstrak
Penelitian ini bertujuan untuk membuat aplikasi pengenalan huruf dan angka bagi taman kanak-kanak dengan pendekatan realistik dengan platforfm android. Adanya pandemi covid-19 ini mengakibatkan pembelajaran dilakukan secara daring mulai dari tingkat TK sampai perguruan tinggi. Metode penelitian yang digunakan dalam penelitian ini adalah $\mathrm{RnD}$ (Research and Development) dengan menggunakan pendekatan ADDIE (Analysis, Design, Development, Implementation, Evaluation). Riset ini sudah sampai tahap ujicoba secara terbatas. Hasil dari penelitian ini adalah tahapan Analisis yaitu peneliti melakukan analisis kebutuhan pada lokasi riset yaitu taman kanak-kanak yang ada di Jakarta. Tahapan design yaitu peneliti melakukan rancangan berupa desain dari aplikasi yang akan dibuat dan tomboltombol apa yang diperlukan dalam tampilan layar yang akan digunakan. Tahapan development yaitu peneliti melakukan pembuatan aplikasi yang sudah siap untuk di ujicoba secara sederhana dan terbatas untuk dapat melihat apa masukan, kelebihan dan kekurangan pada aplikasi yang telah dibuat. Tahapan selanjutnya dalah evaluasi dengan melakukan perbaikan-perbaiukan yang atas masukan apkar dan hasil ujicoba terbatas yang dilakukan pada tahapan implementasi.

Kata Kunci: Aplikasi pengenalan huruf; pengenalan angka; pendekatan realistik, aplikasi pembelajaran android.
\end{abstract}

\begin{abstract}
This research intends to create a letter and number recognition application for kindergarten with a realistic approach using Android. The outbreak of the Covid 19 pandemic has resulted online learning from the level of kindergarten to college students. The research method used was RnD (Research and Development) using ADDIE (Analysis, Design, Development, Implementation, Evaluation) approach. This research has come to the stage of limited trial. The result of this research was the analysis stage, in which the researcher conducted a needs analysis at the research location, kindergartens in Jakarta. The design stage where the researcher created a design of the application and what buttons were needed in the screen display. The development stage where the researcher created an application that was ready to be tested in a simple and limited way to be able to see the inputs, advantages and disadvantages in the application. The next stage was an evaluation by creating improvements based on apkar input and the results of limited trials carried out at the implementation stage.
\end{abstract}

Keyword: Letter recognition application; number recognition; realistic approach, android learning application.

\section{PENDAHULUAN}

Pandemi yang melanda saat ini menjadikan tantangan bagi guru bagaimana dapat memberikan pembelajaran kepada siswa yang tetap menyenagkan khusunya bagi anak taman kanak-kanak. Tantangan ini pun diharapkan dapat menjadi peluang untuk guru kreatif dalam menyajikan pembelajaran yang tidak monoton dan tidak membosankan terlebih siswa taman kanakkanak sangat mudah bosan dan kurang fokus dalam kegiatan pembelajaran.
Pembelajaran dikemas dalam bentuk permainan yang menyenangkan bagi sebagain besar.

Perkembangan teknologi yang sangat pesat menghasilkan hal-hal baru, baik secara umum maupun teknologi perkembangan teknologi dalam dunia pendidikan [1]. Sudah begitu banyak aplikasi pembelajaran khusus taman kanak-kanak yang ada untuk membantu siswa dalam pembelajaran mengenal huruf dan angka. Aplikasi ini 
digunakan untuk menjembatani pengetahun siswa tentang bagaimana siswa tau bagaimana lambang bilangan dan pelafalan dari sebuah angka. Siswa juga diharapkan dapat mengetahui huruf abjad dari huruf $A$ sampai $\mathrm{Z}$ dengan menberikan contoh kata yang dimulai dati huruf tersebut.

Sebenarnya tanpa disadari siswa pernah bermain permainan tebak-tabakan abjad yang menggunakan dari mereka yang diurutkan abjadnya. Lalu menebak kata apa yang awalanya dari huruf tersebut sesuai dengan persyaratan kata tersebut berkaitan dengan apa misal adalah nama-nama hewan. Ketika sudah mengurutkan abjad yang ditentukan dimulai dari $\mathrm{K}$ misalnya nama-nma hewan maka anak tersbut menyenbutkan nama hewan yang berawalan K secara bergantian.

Namun permainan ini sulit untuk dilakukan secara virtual maka dari itu perlu adanya suatu aplikasi yang dapat membantu siswa untuk tetap dapat belajar sambil bermain khususnya anak TK. Penelitian ini diharapkan mampu memberikan kontribusi sebagai media pembelajaran e-learning.

Aplikasi pengenalan huruf dan abjad dapat digunakan untuk memudahkan proses pembelajaan terhadap anak-anak usia dini. Salah satu metode pembelajaran yang telah digunakan secara komersial. Aplikasi berbasis Audio atau suara merupakan suatu aplikasi yang sangat berguna untuk mengurangi rasa bosan, mengurangi rasa jenuh dalam hal belajar karena sangat mudah dalam penggunaannya [2]. Aplikasi ini dapat digunakan sebagai bagian dari penggunaan pembelajaran yang dapat meningkatkan kemampuan siswa taman kanak-kanak sehingga siswa tidak merasa jenuh dan bosa dalam melakukan kegiatan pembelajaran secara daring.

\section{METODE}

ADDIE model is widely used by educators in instructional design worldwide [3]. Metode yang digunakan dalam penelitian ini adalah RnD (Research and Development) dengan pendekatan ADDIE (Analysis, Design, Development, Implementation, Evaluation). Penelitian Reseach and Development adalah metode penelitian yang digunakan untuk menghasilkan produk tertentu dengan menguji keefektifan produk tersebut. Penelitian dan pengembangan (Reseach and Development) merupakan metode penelitian yang digunakan untuk mengembangkan atau memvalidasi produkproduk yang digunakan dalam pendidikan dan pembelajaran [4]. Penelitian ini dilakukan mulai dari Oktober 2020 sampai dengan Januari 2021 lokasi peneliian ini alah siswa taman kakank-kanak Taman Harapan 2 yang belokasi di Jakarta Timur, dengan mengacu pada analisis kebutuhan pada sekolah yang menjadi tempat penelitian berdasarkan analisis kebutuhan yang telah dilakukan. Selain itu penulis juga melakukan berbagai studi pustaka terkait apa saja kebutuhan dan aplikasi apa saja yang sudah tersedia dalam android.

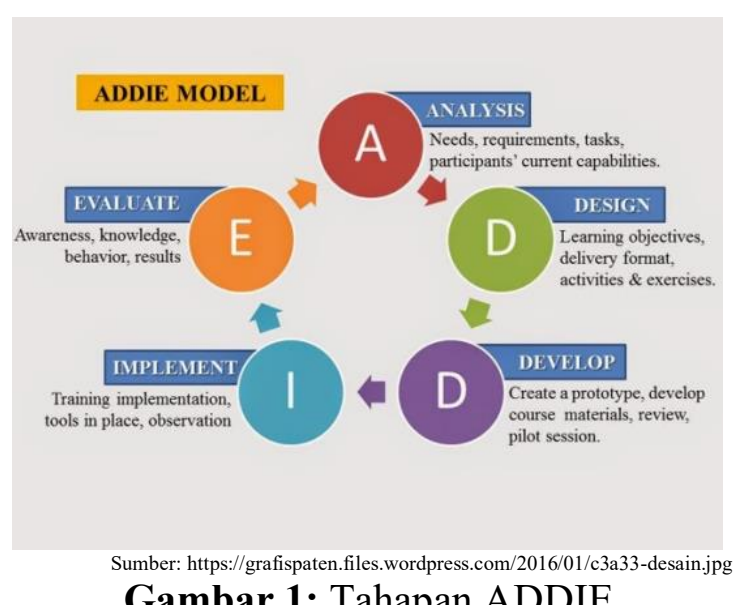

Gambar 1: Tahapan ADDIE

Penelitian ini untuk membuat bagaimana aplikasi ini dapat bermanfaat dalam masa pembeajaran daring dimasa pandemic khususnya untuk usia taman kanak-kanak. Tahapan ADDIE dalam riset ini baru pada terbatas pada tahapan implementasi dengan 
ujicoba terbatas untuk mengetahui kekurngan dan masukan dari para pakar tentang aplikasi yang telah dibuat. Selanjutnya adalah tahapan evaluasi yang dimana peneliti melakukan revisi dan perbaikan atas masukan dari pakar dan hasil ujicoba skala kecil pada tahapan implementasi.

\section{HASIL DAN PEMBAHASAN}

Penelitian ini menghasilkan aplikasi pembelajaran pengenalan huruf dan angka untuk anak usia taman kanak-kanak. Pembelajaran secara daring ini membuat kewalahahan baik itu siswa, orang tua dan guru sendiri. Perlu adanya strategi guru untuk memberikan pembelajaran yang menyenangkan dan tidak membosankan secara daring. Anak usia 5- 7 tahun mempunyai tantangan sendiri dalam memberikan pembelajaran khususnya pada tahapan pengenalan huruf dan angka. Perlu adanya alat peraga karena memang anak taman kanak-kanak memerlukan materi yang realistik.

1. Analisys

Tahapan analisis dimulai dari studi pustaka yang penulis lakukan yaitu dengan mengkaji beberapa jurnal/ artikel yang terkait dengan penelitian pengembangan media pembelajaran pengenalan huruf dan angka. Aplikasi pembelajaran pengenalan huruf dan angka sangat diperlukan untuk meningkatkan kemampuan siswa dalam memahami lambang bilangan dan juga mengetahui bentuk dan pelafalan huruf $[5][6][7]$.

Selanjutnya penulis melakukan wawancara dengan guru tentang analisis kebutuhan terkait media pembelajaran yang efektif dan efiesen yang digunakan selama pembelajaran daring.

\section{Design}

Tahapan desain dilakukan dengan menggunakan data-data yang dibutuhkan seperti referensi gambar, referensi angka, warna-warna, dan juga tamplet dari aplikasi yang digunakan dalam mendesain dari aplikasi yang kan digunakan.

\section{Development}

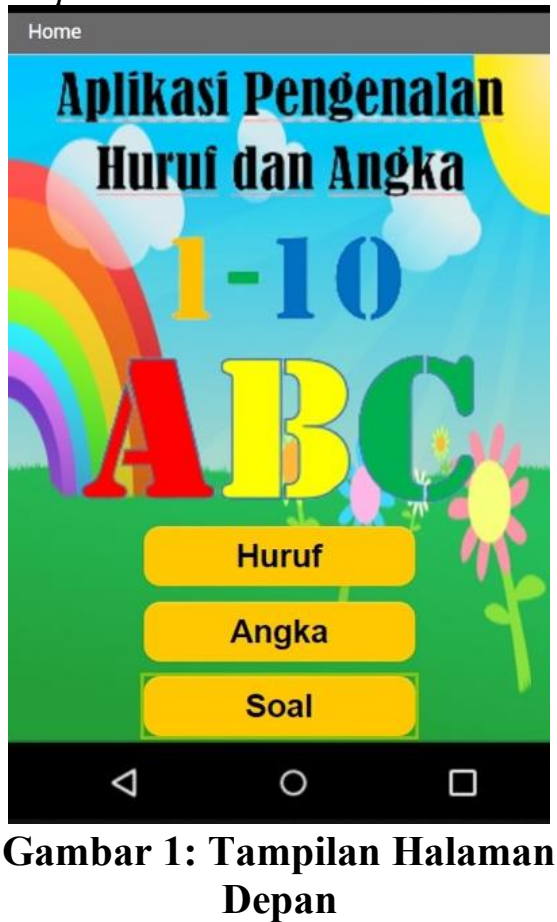

Tampilan halaman depan ini menggunakan baground, dengan warna cerah hal ini dimaksudkan agar dari segi tampilan dapat membuat minat siswa untuk melihat tampilan layar menjadi lebih termotivasi karena memang untuk anak-anak tingkat taman kanak-kanak memerlukan warna-warna yang cerah dan mencolok sebagai bagian dari untuk siswa. Pada tampilan home ini berandanya terdapat menu huruf, angka dan soal. Lalu ada angka 1-10 sebagai bagian simbol lambang bilangan yang akan di perkenalkan kepada siswa. Selanjutnya ada simbol huruf ABC sebagai bagian dari tampilan yang memang umumnya mewakili huruf abjad. 


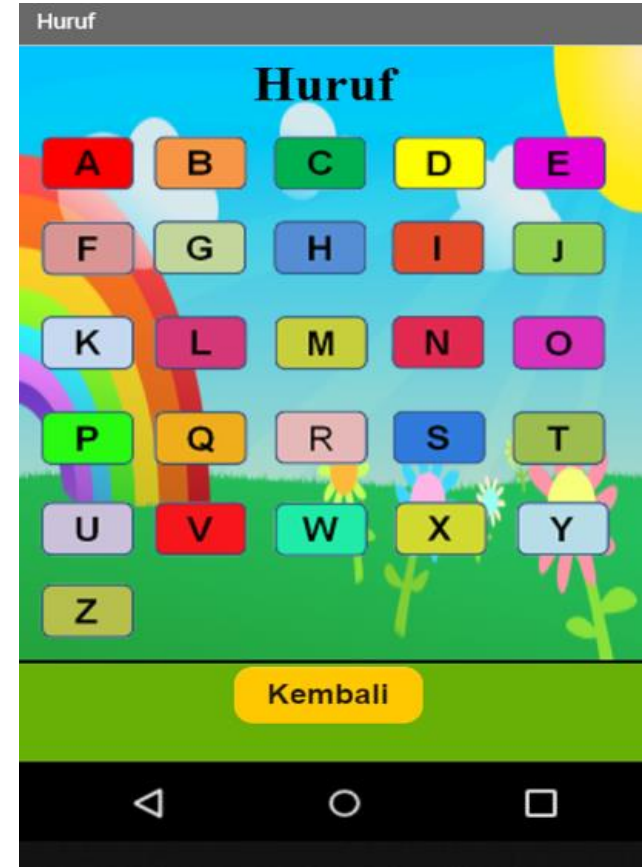

Gambar 2: Tampilan Menu Huruf

Ketika kita mengkli menu huruf maka akan tampil huruf abjad dari A sampai dengan $Z$. untuk dapat mengetahui cara pelafalan huruf tersbeut maka ketika di klik salah satu huruf maka kan masuk ke munu selanjutnya seperti pada gambar 3 dengan adanya bunyi huruf $\mathrm{A}$ pelafalannya.

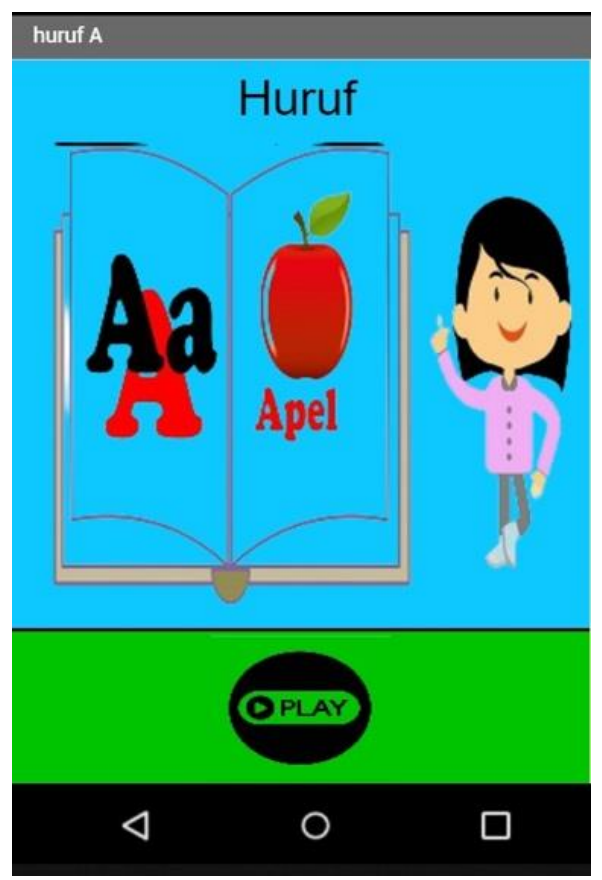

Gambar 3: Tampilan Menu Huruf A
Pada gambar 3 ini adalah lanjutan dari huruf yang di klik tadi sehingga muncul salah satu contoh kata yang berawalan dari huruf yang di klik. Sebagai contoh yang diklik adalah hurud A maka ketika kita tekan tombol play pada tampilan layer, akan berbunti contoh pelafan gambar contoh kata yang ada pada gambar yaitu "Apel" sedangkan pada huruf lainya sesuai dengan nama-nama awalannya. B adalah "Bebek" dan lainya sebagainya sesuai dengan huruf awalnya.

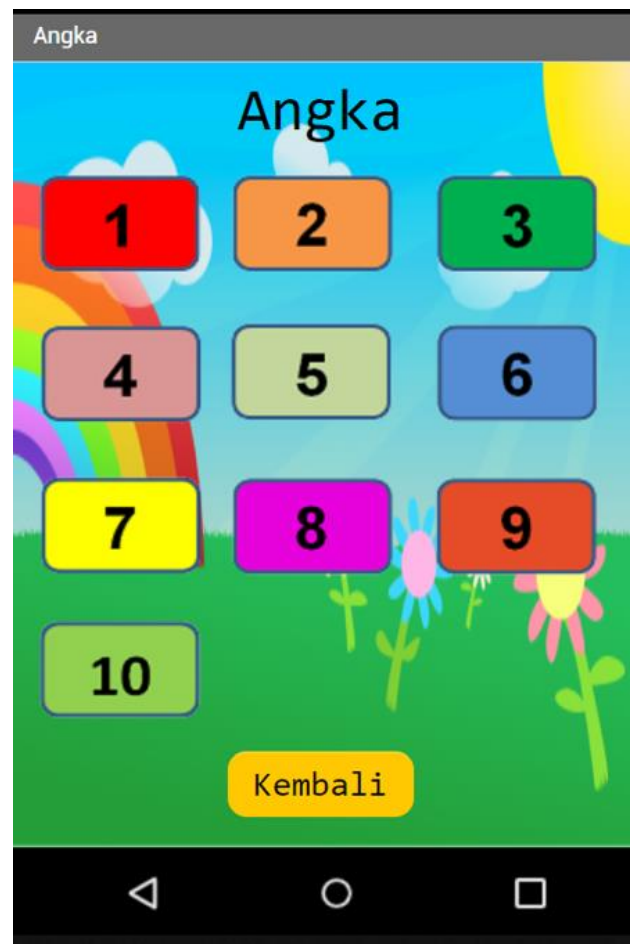

Gambar 4: Tampilan Menu Angka

Tombol menu yang kedua itu adalah angka, pada tampilan angka ini memuat angka dari 1-10 dimana ini juga sama pengenalan lambang bilangan angka dan cara pelafalannya. Ketika kita klik angka 3 misalnya maka akan tampilan layar pada gambar 5. 


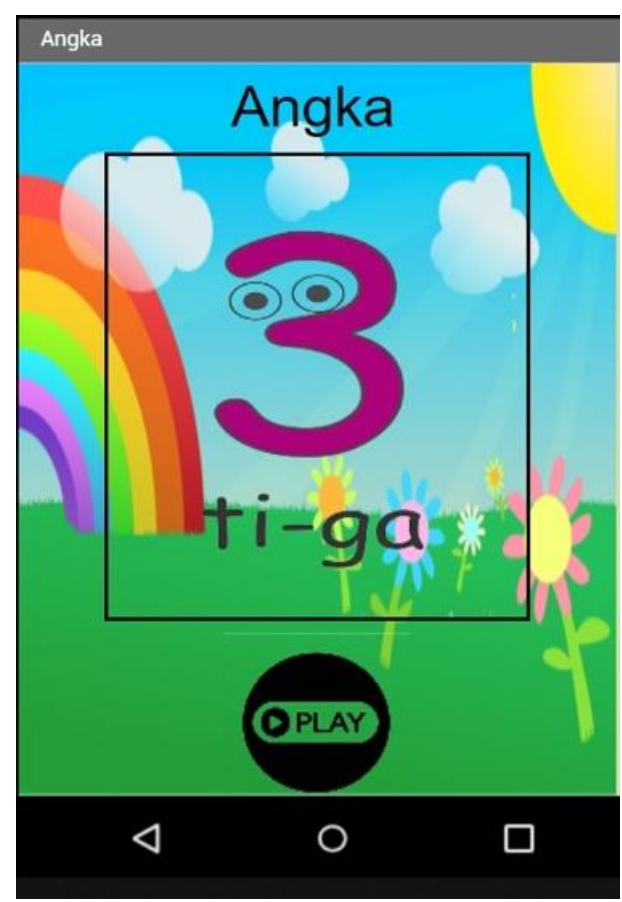

Gambar 5: Tampilan Menu Angka 3

Tampilan layer ketika mengklik angka 3 maka akan telihat tampilan layar pada gambar 3. Ketika kita klik play maka akan terdengar pelafalan cara membaca lambang bilangan "tiga". Untuk angka yang lainya juga sama akan terlihat angkanya dan juga ketika di klik play maka akan terdengan suara pelafannya angka yang diklik tadi.

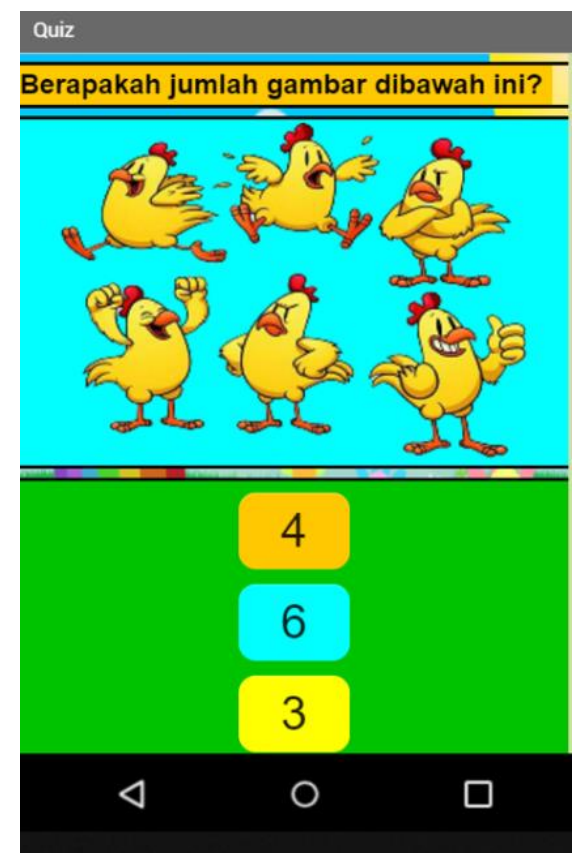

Gambar 6: Tampilan Menu Kuis
Menu kuis ini adalah mereka berhitung berapa jumlah gambar yang terlihat pada tampilan layer. Sebagai contoh ini terdapat 6 ekor ayam. SIswa diminta untuk memilih berpa jumlah ayam yang ada pada tampilan layear ini sesuai dengan matematika realistic. Siswa taman kanak-kanak hanya dapat berpikir secara realistik artinya siswa tersebut melihat dan merasakan apa yang menjadi bagian dari bagian pembelajaran.

\section{Implemensi}

Tapahan implementasi ini baru pada sampai ujicoba skala terbatas dengan melibatkan beberapa siswa yang didampingi oleh orang tuanya dengan memberikan masukan tentang apa saja yang harus diperbaiki. Selanjutnya aplikasi yang sudah jadi ini diberikan kepada guru untuk memberikan penilaian dan masukan terkait dari aplikasi ini apa saja yang harus diperbaiki serta diberikan kepada pakar desain yaitu untuk melihat bagiamana data saling tekait dengan memberikan masukan kepada penulis untuk dapat diperbaiki

\section{Evaluasi}

Tahapan evaluasi ini untuk memperbaiki dari hasil implementasi yang telah dilakukan. Hasil dari tahapan evalusi ini maka produk yang telah jadi dan siap untuk dipergunakan dalam melakukan pembelajaran secar daring dengan menggunakan aplikasi pembelajaran pengenalan huruf dan angka.

Usia dini merupakan usia yang sangat penting bagi perkembangan anak sehingga disebut Golden Age [8]. Pada usia ini diharapkan kemampuan berpikir anak dapat berembang baik dari sisi kognitif dan psikologis. Kemampuan realistic anak 
dapat tunjang dengan berbagai kemampuan pengenalan kemampuan terakit dengan kemapuan mengenal huruf dan angka dalam upaya meningkatkan kemampuan kognitis siswa. Peran orang tua sangat penting dalam perkembangan teknologi yang semakin hari semakin canggih. Orang tua harus cermat membimbing anak dalam penggunaan smartphone mobile. Adapun hal positif bagi penggunaan smartphone android untuk anak, antara lain menambah pengetahuan anak secara mudah, memperluas jaringan pertemanan anak dan mempermudah komunikasi anak [9]. Pada penerapan aplikasi ini perlu adanya bimbingan dan pengawasan dari guru sehingga guru dapat melihat perkembangan anak [10]. Peran orang tua ketika pebelajaran daring dilakukan dirumah menjadi sangat penting oleh karena itu diharapkan orang tua dapat membimbing putra-putrinya ketika pembelajaran dengan menggunakan gadget hal ini untuk memimalisir penyalahgunaan gadget ketika di pegang oleh anak. Guru hendaknya memberikan arahan kepada siswa untuk dapat lebih bijak atas penggunakan gadget sebagai media pembelajaran daring yang dilakukan saat ini.

\section{SIMPULAN}

Berdasarkan hasil dan pembahasan yang telah dipaparkan sebelumnya maka dapat disimpulkan bahwa aplikasi pengenalan huruf dan angka ini dapat digunakan sebagai media pembelajaran e-learning. Aplikasi ini diharapkan dapat membantu guru dan siswa serta orang tua khusunya tingkat taman kanak-kanak dalam memahami bilangan matematika dan huruf serta pelafalanya. Aplikasi ini juga dapat bermanfaat untuk meningkatkan kemampuan siswa untuk mengetahi beberapa contoh bentuk angka dan huruf.

\section{DAFTAR PUSTAKA}

[1] I. Z. Fauziah, Sutrisno, and Suwarni, "Pengembangan E-Modul Berbasis
Adobe Flash CS6 pada Mata Pelajaran Penataan Barang Dagang," J. Pendidik. Bisnis dan Manaj., vol. 2, no. 2, pp. 154-159, 2016, doi: 10.15713/ins.mmj.3.

[2] J. R. Sagala, "Implementasi palikasi pengenalan huruf dan angka berbasis audio pada yayasan pendidikan katolik TK. RK. ST. Thomas Medn," J. Mantik Penusa, vol. 16, no. 2, pp. 22-27, 2014.

[3] R. S. Nadiyah and S. Faaizah, "The Development of Online Project Based Collaborative Learning Using ADDIE Model," Procedia - Soc. Behav. Sci., vol. 195, pp. 1803-1812, 2015 , doi: 10.1016/j.sbspro.2015.06.392.

[4] S. Hartati, N. A. K. Dewi, D. Puastuti, M. Muslihudin, and N. S. Budi, "Sistem Aplikasi Educhat Stmik Pringsewu Berbasis Android Sebagai Media," Teknosi, vol. 03, no. 01, pp. 143-152, 2017.

[5] S. Bakhri, "Animasi interaktif pembelajaran huruf dan angka menggunakan model ADDIE," INTENSIF J. Ilm. Penelit. dan Penerapan Teknol. Sist. Inf., vol. 3, no. 2, pp. 130-144, 2019, doi: 10.29407/intensif.v3i2.12666.

[6] Suyono and R. Wati, "Aplikasi pengenalan huruf,gambar dan warna pada PAUD Mutiara Sari Podorejo Kecamatan Pringsewu berbasis android," Technologia, vol. 12, no. 1, pp. 20-24, 2021.

[7] S. Saputra, "Pengembangan Media Pembelajaran Pengenalan Huruf Dan Angka Untuk Anak Taman Kanakkanak (TK)," in Seminar Nasional Teknologi Infomasi dan Komputer, 2019, pp. 94-102.

[8] D. L. Fithri and D. A. Setiawan, "Analisa san perancangan game edukasi sebagai motivasi belajar untuk anak usia dini," Simetris J. Tek. Mesin, Elektro dan Ilmu 
Komput., vol. 8, no. 1, pp. 225-230, 2017, doi: 10.24176/simet.v8i1.959.

[9] T. W. Pratama, I. P. Astuti, and G. A. Buntoro, "Aplikasi pengenalan benda sekitar untuk anak autis berbasis android," KOMPUTEK (Jurnal Tek. Univeristas Muhammadiyah Ponorogo), vol. 3, no. 2, pp. 87-104, 2019.

[10] M. T. Chulkamdi and S. Purnomo,
"Perancangan dan implementasi game interaktif pengenalan huruf dan angka untuk media pembelajaran di PAUD Wachid Hasyid Ponggok Kabupaten Bliktar," J. Antivirus, vol. 10, no. 1, pp. 21-31, 2016, doi: 10.35457/antivirus.v10i1.84. 